\title{
Front Matter: Volume 8184
}

, "Front Matter: Volume 8184," Proc. SPIE 8184, Unmanned/Unattended Sensors and Sensor Networks VIII, 818401 (26 October 2011); doi: 10.1117/12.917238

SPIE. Event: SPIE Security + Defence, 2011, Prague, Czech Republic 


\section{PROCEEDINGS OF SPIE}

\section{Unmanned/Unattended Sensors and Sensor Networks VIII}

Edward M. Carapezza

Editor

20-21 September 2011

Prague, Czech Republic

Sponsored and Published by

SPIE

Volume 8184

Proceedings of SPIE, 0277-786X, v. 8184 
The papers included in this volume were part of the technical conference cited on the cover and title page. Papers were selected and subject to review by the editors and conference program committee. Some conference presentations may not be available for publication. The papers published in these proceedings reflect the work and thoughts of the authors and are published herein as submitted. The publisher is not responsible for the validity of the information or for any outcomes resulting from reliance thereon.

Please use the following format to cite material from this book:

Author(s), "Title of Paper," in Unmanned/Unattended Sensors and Sensor Networks VIII, edited by Edward M. Carapezza, Proceedings of SPIE Vol. 8184 (SPIE, Bellingham, WA, 2011) Article CID Number.

ISSN 0277-786X

ISBN 9780819488121

Published by

SPIE

P.O. Box 10, Bellingham, Washington 98227-0010 USA

Telephone +1 3606763290 (Pacific Time) · Fax +1 3606471445

SPIE.org

Copyright (C) 2011, Society of Photo-Optical Instrumentation Engineers

Copying of material in this book for internal or personal use, or for the internal or personal use of specific clients, beyond the fair use provisions granted by the U.S. Copyright Law is authorized by SPIE subject to payment of copying fees. The Transactional Reporting Service base fee for this volume is $\$ 18.00$ per article (or portion thereof), which should be paid directly to the Copyright Clearance Center (CCC), 222 Rosewood Drive, Danvers, MA 01923. Payment may also be made electronically through CCC Online at copyright.com. Other copying for republication, resale, advertising or promotion, or any form of systematic or multiple reproduction of any material in this book is prohibited except with permission in writing from the publisher. The CCC fee code is 0277-786X/11/ \$18.00.

Printed in the United States of America.

Publication of record for individual papers is online in the SPIE Digital Library.

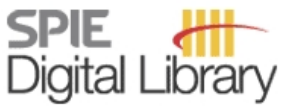

SPIEDigitalLibrary.org

Paper Numbering: Proceedings of SPIE follow an e-First publication model, with papers published first online and then in print and on CD-ROM. Papers are published as they are submitted and meet publication criteria. A unique, consistent, permanent citation identifier (CID) number is assigned to each article at the time of the first publication. Utilization of CIDs allows articles to be fully citable as soon as they are published online, and connects the same identifier to all online, print, and electronic versions of the publication. SPIE uses a six-digit CID article numbering system in which:

- The first four digits correspond to the SPIE volume number.

- The last two digits indicate publication order within the volume using a Base 36 numbering system employing both numerals and letters. These two-number sets start with 00, 01, 02, 03, 04, $05,06,07,08,09,0 A, 0 B \ldots 0 Z$, followed by 10-1Z, 20-2Z, etc.

The CID number appears on each page of the manuscript. The complete citation is used on the first page, and an abbreviated version on subsequent pages. Numbers in the index correspond to the last two digits of the six-digit CID number. 


\section{Contents}

$\checkmark \quad$ Conference Committee

\section{SESSION 1 UNATTENDED SENSORS AND SYSTEMS I}

818404 Pose and class estimation of stationary ground vehicles using a scale augmented parameter set [8184-06]

V. C. Ravindra, V. K. Madyastha, G. Gopalratnam, National Aerospace Labs. (India);

M. Guerriero, Far Systems S.P.A. (Italy)

\section{SESSION 2 UNATTENDED SENSORS AND SYSTEMS II}

818406 Integrated mobile radar-camera system in airport perimeter security [8184-08] M. Życzkowski, M. Szustakowski, W. Ciurapiński, R. Dulski, M. Kastek, P. Trzaskawka, Military Univ. of Technology (Poland)

818408 EO/IR sensor development using nanostructures for unattended ground sensor applications [8184-10]

A. K. Sood, J. W. Zeller, Y. R. Puri, Magnolia Optical Technologies, Inc. (United States);

T. Manzur, Naval Undersea Warfare Ctr. (United States); N. K. Dhar, DARPA/MTO (United

States); A. Rivera, A. F. M. Anwar, Univ. of Connecticut (United States); G. Fernandes,

J. M. XU, Brown Univ. (United States)

818409 Adaptive fusion of infrared and visible images in dynamic scene [8184-11]

G. Yang, Y. Yin, H. Man, Stevens Institute of Technology (United States); S. Desai, U.S. Army RDECOM (United States)

\section{SESSION 3 FORCE PROTECTION AND SECURITY}

$8184 \mathrm{OB} \quad$ Model for small arms fire muzzle blast wave propagation in air [8184-15]

J. R. Aguilar, Academia Politécnica Militar (Chile); S. V. Desai, U.S. Army RDECOM (United States)

\section{SESSION 4 FREE-SPACE OPTICAL COMMUNICATION}

8184 OC Effects of evaporation layer on free-space optical communication links near sea surface at $1.55 \mu \mathrm{m}[8184-16]$

J. Zeller, T. Manzur, Naval Undersea Warfare Ctr. (United States)

8184 OD $\quad 5.625$ Gbps bidirectional laser communications measurements between the NFIRE satellite and an optical ground station [8184-17]

R. A. Fields, D. A. Kozlowski, H. T. Yura, R. L. Wong, J. M. Wicker, C. T. Lunde, The Aerospace Corp. (United States); M. Gregory, B. K. Wandernoth, F. F. Heine, Tesat-Spacecom

(Germany); J. J. Luna, Orbital Sciences Corp. (United States) 
8184 OE Design and early development of a UAV terminal and a ground station for laser communications [8184-18]

A. Carrasco-Casado, R. Vergaz, J. M. Sánchez-Pena, Univ. Carlos III de Madrid (Spain)

8184 OF Nonmechanical beam steering using optical phased arrays [8184-19]

T. E. Dillon, C. A. Schuetz, R. D. Martin, D. G. Mackrides, Phase Sensitive Innovations, Inc.

(United States); P. F. Curt, J. Bonnett, EM Photonics (United States); D. W. Prather, Univ. of

Delaware (United States)

\section{SESSION 5 UNMANNED SYSTEMS TECHNOLOGIES}

$8184 \mathrm{OH} \quad$ A versatile sensor network for urban search and rescue operations [8184-22]

K. Känsälä, M. Korkalainen, A. Mäyrä, VTT Technical Research Ctr. of Finland (Finland)

8184 Ol Managing heterogeneous networks of mobile and stationary sensors [8184-23]

A. Bürkle, P. Solbrig, F. Segor, D. Bulatov, P. Wernerus, S. Müller, Fraunhofer IOSB (Germany)

$81840 \mathrm{~J} \mathrm{Towards}$ the development of tamper-resistant, ground-based mobile sensor nodes [8184-24]

D. Mascareñas, C. Stull, C. Farrar, Los Alamos National Lab. (United States)

Author Index

iv 


\title{
Conference Committee
}

\author{
Symposium Chairs
}

David H. Titterton, Defence Science and Technology Laboratory (United Kingdom)

Reinhard R. Ebert, Fraunhofer-Institut für Optronik, Systemtechnik und Bildauswertung (Germany)

Čestmír Vlček, University of Defence (Czech Republic)

Conference Chair

Edward M. Carapezza, Defense Advanced Research Projects Agency (United States) and University of Connecticut (United States)

Programme Committee

James S. Albus, National Institute of Standards and Technology (United States)

A. F. Mehdi Anwar, University of Connecticut (United States)

Mark E. Campbell, Cornell University (United States)

Pierre J. Corriveau, Naval Undersea Warfare Center (United States)

Sachi V. Desai, U.S. Army Armament Research, Development and Engineering Center (United States)

John M. Dolan, Carnegie Mellon University (United States)

Grant R. Gerhart, U.S. Army Tank-Automotive Research, Development and Engineering Center, Retired (United States)

Todd M. Hintz, Space and Naval Warfare Systems Command (United States)

Myron E. Hohil, U.S. Army Armament Research, Development and Engineering Center (United States)

Ivan Kadar, Interlink Systems Sciences, Inc. (United States)

Leslie Laycock, BAE Systems (United Kingdom)

Tariq Manzur, Naval Undersea Warfare Center (United States)

George McNamara, Naval Undersea Warfare Center (United States)

Nino Srour, U.S. Army Research Laboratory (United States)

Huub A. J. M. van Hoof, TNO Defence, Security and Safety

(Netherlands)

Henry J. White, BAE Systems (United Kingdom) 
Session Chairs

1 Unattended Sensors and Systems I

Sachi V. Desai, U.S. Army Armament Research, Development and Engineering Center (United States)

Myron E. Hohil, U.S. Army Armament Research, Development and Engineering Center (United States)

2 Unattended Sensors and Systems II

Ferhat Culfaz, BAE Systems (United Kingdom)

Tariq Manzur, Naval Undersea Warfare Center (United States)

3 Force Protection and Security

Sachi V. Desai, U.S. Army Armament Research, Development and Engineering Center (United States)

Tariq Manzur, Naval Undersea Warfare Center (United States)

4 Free-Space Optical Communication

Tariq Manzur, Naval Undersea Warfare Center (United States)

Sachi V. Desai, U.S. Army Armament Research, Development and Engineering Center (United States)

$5 \quad$ Unmanned Systems Technologies

Tariq Manzur, Naval Undersea Warfare Center (United States) 